\title{
Research on invasive pests and diseases in New Zealand and the law
}

\author{
D.A.J. Teulon ${ }^{1}$, K.S.H. Boyd Wilson ${ }^{1}$, A. Holton ${ }^{1}$ and G.S. Ridley ${ }^{2}$ \\ ${ }^{1}$ The New Zealand Institute for Plant E Food Research Limited, Private Bag 4704, \\ Christchurch, New Zealand \\ ${ }^{2}$ Environmental Protection Authority, PO Box 131, Wellington 6140, New Zealand \\ Corresponding author:david.teulon@plantandfood.co.nz
}

\begin{abstract}
Two New Zealand statutes have important implications for research with organisms not previously found in New Zealand and either incidentally or illegally introduced. The Biosecurity Act 1993 and the Hazardous Substances and New Organisms Act 1996 define the legal framework and allowable activities for 'unwanted' and 'new' organisms, respectively. Aspects of these Acts that are relevant to research activities possible with plant pest and disease organisms after their discovery, in particular those organisms requiring rapid development of management strategies and tools, are summarised. The need for accurate, detailed and accessible lists of 'unwanted' and 'new' organisms, and the need for the Ministry for Primary Industries (MPI) and the Environmental Protection Authority (EPA) to respond rapidly when the status of these organisms needs to be changed is highlighted. Consideration should be given to making the legislation concerning 'new' organisms more applicable to incidentally or illegally introduced organisms.
\end{abstract}

Keywords new organisms, unwanted organisms, pest, disease, incursion.

\section{INTRODUCTION}

New Zealand productive (e.g. pastures, crops, orchards, plantation forests) and natural systems are subject to continued invasion by new pest and disease species from overseas (see Goldson \& Suckling 2003; Kriticos et al. 2005; Froud et al. 2008), and this is likely to increase with increased trade (Liebhold et al. 2012) and international travel. In some cases, these new species are known to be sufficiently damaging to these productive and natural ecosystems that new pest management strategies and tools need to be developed rapidly. Recent examples include the clover root weevil Sitona lepidus (Eerens et al. 2005), the potato tomato psyllid
Bactericera cockerelli and Candidatus Liberibacter solanacearum (Teulon et al. 2009), the causal agent of kiwifruit bacterial canker Pseudomonas syringae pv. actinidiae (Psa) (Everett et al. 2011a), the Monterey pine aphid Essigella californica (Flynn et al. 2003), and Didymosphenia geminata (Lyngbye) Schmidt (commonly known as didymo) (Bickel \& Closs 2008).

The Ministry for Primary Industries (MPI) was formed on 30 April 2012 as a result of the merger of the New Zealand Food Safety Authority, the Ministry of Fisheries and the Ministry of Agriculture and Forestry. MPI investigates all suspected new pest or disease species found in 
New Zealand. Its response includes establishing the identity of the new incursion (i.e. genus/ species name), determining its distribution within New Zealand, assessing its likely impact on New Zealand's productive and natural ecosystems, undertaking a cost/benefit analysis of likely impact and management response, and the feasibility of either eradication or long-term management (MAFBNZ 2008a). In many cases, where eradication is not considered feasible, there is a need for research to support the rapid development of new systems and tools for management of these new species once they are considered permanently established in New Zealand.

Two New Zealand statutes have important implications for conducting research on new pest and disease organisms that have been either incidentally (a new organism that is imported in or on goods, with some specific exceptions) or illegally introduced into New Zealand. These are the Biosecurity Act 1993 and the Hazardous Substances and New Organisms Act 1996 (HSNO), which define the legal framework and allowable activities for 'unwanted' and 'new' organisms, respectively.

This paper highlights some of the important issues that are pertinent to research activities carried out with pest and disease organisms after they have been discovered in New Zealand. The aim is not to interpret the legal intention of these Acts, but to identify some issues that plant protection researchers need to consider when working with new pest and disease incursions within New Zealand, and to suggest ways to make that activity more effective with respect to the law. This paper does not concern itself with the introduction of new biological control agents into New Zealand or the development of new genetically modified organisms, which both have clear status as new organisms.

\section{Biosecurity Act 1993}

This Biosecurity Act provides a legal basis for excluding, eradicating and managing pests and diseases and unwanted organisms, and its powers can be variously used by MPI, other government agencies, regional councils and pest management agencies (Biosecurity Act 1993). The Act provides a range of functions, powers and options for the management of risk organisms (MAFBNZ 2008b). The Biosecurity Act is administered by MPI giving it considerable powers to respond to new pest and disease incursions within New Zealand (MAFBNZ 2008a).

The Act defines an 'unwanted organism' as 'any organism that a Chief Technical Officer believes is capable or potentially capable of causing unwanted harm to any natural and physical resources or human health'. These organisms may or may not already be present in New Zealand. This definition also includes any 'new' organism that EPA has declined approval to import (an unlikely scenario for most pests and diseases) and any organism specified in Schedule 2 of the HSNO Act (no invertebrate plant pests or diseases are listed there).

The Biosecurity Act also places a general duty on all persons in New Zealand to inform the MPI (as MAF in the Act) of the presence of an organism not normally seen in New Zealand (Section 44) or a 'notifiable' organism (Section 46), respectively.

The Biosecurity Act stipulates activities that cannot be carried out with 'unwanted organisms' (Section 52) (prohibited activities.). "No person shall knowingly communicate [Oxford English Dictionary $=$ transmit $]$, cause to be communicated, release [no definition within the Act but in relation to 'new organisms' this means to allow the organism to move within New Zealand free of any restrictions other than those imposed in accordance with the Biosecurity Act 1993 or the Conservation Act 1987], or cause to be released, or otherwise spread, any pest or unwanted organism except" under special circumstances largely governed by MPI. Additionally, the Act stipulates "that the owner or person in charge of an organism which that person knows or suspects constitutes, contains, or harbours a pest or 'unwanted' organism" must not "propagate, breed, or multiply the pest or 'unwanted' organism or otherwise act in such a manner as is likely to encourage or cause the propagation, breeding, or multiplication of the pest or 'unwanted' organism" (Section 53 (1)(c). 
Making an organism 'unwanted' triggers actions to be taken to manage the organism at the border or to require any activitiy (e.g. research) within New Zealand to be approved. In order to conduct research on an 'unwanted' organism, permission must be obtained from MPI (see MAFBNZ 2010a) and generally needs to be carried out under containment conditions.

\section{Hazardous Substances and New Organisms Act 1996 (the 'HSNO' Act)}

The purpose of the HSNO Act is to protect the environment, and the health and safety of people and communities, by preventing or managing the adverse effects of hazardous substances and 'new' organisms (HSNO 1996). The Act defines what is a 'new organism' (Section 2A (1)) and what is not (Section 2A (2)). A pest or disease species regarded as having newly invaded New Zealand is very likely to be a 'new organism' because it is 'an organism belonging to a species that was not present in New Zealand immediately before 29 July 1998'. It may also be a 'new organism' if it 'belongs to a species, subspecies, infrasubspecies, variety, strain, or cultivar that has been eradicated from New Zealand' such as the white-spotted tussock moth, Orgyia thyellina (Morgan 1998). The Act is not clear if this relates to organisms first found before and/or after 29 July 1998 and is clearly problematic where there is disagreement over whether a newly discovered organism is the result of a new introduction or merely a failed eradication as is the case with the Mediterranean fruit fly (Ceratitis capitata) in California (Myers et al. 2000). The Act does, however, makes it clear that a 'new organism does not cease to be a new organism because it is an incidentally imported new organism', as is likely to be the case with many new pest and disease incursions or 'because it is subject to a conditional release approval', or 'because it is a qualifying organism approved for release with controls. The last two conditions are unlikely to be relevant for pest and disease species.

A range of activities using new organisms are prohibited without HSNO approval (Section 25 (1)(b)). Approval is required to import, develop, field test, or release new organisms. These terms are described below.

- 'Import' relates to intentional importation of the organism into New Zealand and generally into containment. This would seem to be a reasonable restriction in most cases.

- 'Develop', in relation to incidentally imported organisms, includes 'the deliberate isolation, aggregation, multiplication, or other use of the organism. This could be interpreted as prohibiting the rearing of new pest organisms for research purposes and, it is suggested that this requires further policy consideration.

- 'Field test' means 'the carrying on of trials on the effects of the organism under conditions similar to those of the environment into which the organism is likely to be released, but from which the organism, or any heritable material arising from it, could be retrieved or destroyed at the end of the trials'. This definition seems to relate to newly introduced biological control agents or newly developed genetically modified organisms. It does not explicitly rule out incidentally imported organisms', so its application to research on new pest and disease incursions is not clear and requires further policy consideration.

- 'Release', in relation to new organisms, means 'to allow the organism to move within New Zealand free of any restrictions other than those imposed in accordance with the Biosecurity Act 1993 or the Conservation Act 1987'. This could be interpreted as prohibiting the movement of an established pest new organism between laboratories (i.e. not under containment) or its release onto field sites, despite these pests exisiting outside containment in fields or orchards. Again, another area worthy of policy consideration.

The HSNO Act also allows for MPI, or its agents, to isolate, aggregate, multiply, or use an incidentally imported new organism for the purpose of identifying, managing, or eradicating that organism (Section 25 (1B)) but this option does not seem to be used very often for research purposes. However, what constitutes an agent is not clear and requires further policy consideration. 


\section{DISCUSSION}

In the following discussion, some of the issues that need to be considered before undertaking research for the management of new pest and disease incursions in New Zealand are highlighted, and some recommendations on how these might be addressed are provided.

\section{Determination of 'unwanted' and 'new' organisms}

MPI keeps a searchable on-line register of unwanted and notifiable organisms that it has considered (MAF BNZ 2010b), although there are undoubtedly many other species that could be added if additional risk assessments were carried out. Similarly, the EPA maintains a publicly available list of organisms where decisions on the 'new' or 'not new' status have been considered, and there are working lists of organisms that require further information. Organisms are added to these lists as new information becomes available.

It is usually very clear whether an organism is 'unwanted' or not, as it is specifically designated as such by MPI. However 'new' organisms are determined primarily through interpretation of section 2A of the HSNO Act. Many newly discovered invasive organisms would clearly be 'new' organisms, for example the gypsy moth, Lymantria dispar, and related species, which are the subject of a national surveillance programme (Brockerhoff et al. 2010). However, in some cases it is not clear whether or not a new pest or disease species is a 'new' organism. For example, the causal agent of the zebra chip disease in potatoes (Candidatus Liberibacter solanacearum) (first detected in 2008) may have been introduced with its insect vector host (Bactericera cockerelli) in 2005-2006 (Teulon et al. 2009) or it may have been in New Zealand before then (and before July 1998). Nevertheless, this species was made 'not new' by Order in Council in 2011 under section 140(1)(ba) (SR 2011/299; Hazardous Substances 2011) (see below for further discussion) to make its legal status under the HSNO Act absolutely clear. For similar reasons, a determination on the status of the causal agent of kiwifruit bacterial canker Pseudomonas syringae pv. actinidiae (Psa) was made under Section 26 of the HSNO Act
(EPA 2011). This determined that Psa was not a 'new' organism because it belongs to a species, Pseudomonas syringae, which had already been determined as being not a 'new' organism, even though the specific pathovar was not considered to be in New Zealand before the 2010 outbreak. This process took approximately 2 weeks. Psa remains an 'unwanted' organism under the Biosecurity Act and therefore still subject to regulation.

Lack of clarity around new organisms may also occur for a number of reasons that might require a determination under Section 26 of the HSNO Act (Table 1). Although not all examples are important pests and diseases, they illustrate complexities in categorising which organisms are new and which are not.

\section{Options for research on 'new' organisms}

It is generally considered that the HSNO Act was designed to deal with the possible intentional release following risk assessments of new organisms into New Zealand such as biological control agents or genetically modified organisms, and to distinguish beneficial from detrimental organisms (Upton 1999). However, it does not appear that it was intended to deal efficiently with unintentionally introduced organisms that cannot be eradicated, but must be managed, under the Biosecurity Act. Therefore the options for research on 'new' organisms under the HSNO Act can appear somewhat inappropriate.

There are provisions under the HSNO Act (Section 34) to seek approval from the EPA to 'import for release' and 'release from containment', including a Rapid Assessment (Section 35). The Minimum Standards (Section 36), however, appears to rule out considering any new pest and disease incursion for release since it requires that an application should be declined if the new organism is likely to cause disease, be parasitic, or become a vector for human, animal, or plant disease, as is the case with many pest and disease incursions. EPA can also authorise approval 'to import or release new organisms with controls' (Section 38A), including a Rapid Assessment (Section 38BA), but the nature of new biological invasions and the controls imposed upon them 
Table 1 Examples of organisms where lack of information can lead to uncertainty over their new organism status.

\begin{tabular}{|c|c|c|c|}
\hline Organism (host plant) & Reason for uncertainty & Likely status & Reference \\
\hline $\begin{array}{l}\text { Fusarium } \\
\text { pseudograminearum } \\
\text { (Ascomycota) } \\
\text { (on cereals) }\end{array}$ & $\begin{array}{l}\text { Recently characterised but likely to have } \\
\text { been present in NZ before } 1998 .\end{array}$ & $\begin{array}{l}\text { Organism found in } \\
\text { NZ before } 1998 . \\
\text { Not a new organism. }\end{array}$ & $\begin{array}{l}\text { Monds et } \\
\text { al. } 2005\end{array}$ \\
\hline $\begin{array}{l}\text { Frankliniella } \\
\text { nr. occidentalis } \\
\text { (Thysanoptera) } \\
\text { (on various plants) }\end{array}$ & $\begin{array}{l}\text { A morphologically identical species } \\
\text { to Frankliniella occidentalis has been } \\
\text { found in NZ since the 1930s but is now } \\
\text { considered to be a new species. The } \\
\text { true Frankliniella occidentalis was first } \\
\text { recorded in NZ in the 1980s. }\end{array}$ & $\begin{array}{l}\text { Both organisms } \\
\text { found in NZ before } \\
\text { 1998. Both not new } \\
\text { organisms. }\end{array}$ & $\begin{array}{l}\text { Rugman- } \\
\text { Jones et } \\
\text { al. } 2010\end{array}$ \\
\hline $\begin{array}{l}\text { Megoura stufkensis } \\
\text { (Hemiptera) } \\
\text { (on Carmichaelia) }\end{array}$ & $\begin{array}{l}\text { Regarded as indigenous but no close } \\
\text { known relatives in NZ }\end{array}$ & $\begin{array}{l}\text { Native. Not a new } \\
\text { organism. }\end{array}$ & $\begin{array}{l}\text { Eastop } \\
2011\end{array}$ \\
\hline $\begin{array}{l}\text { Sphaceloma perseae } \\
\text { (Ascomycota) } \\
\text { (on Persea americana) }\end{array}$ & $\begin{array}{l}\text { Wrongly identified in NZ from one } \\
\text { isolate that was subsequently identified as } \\
\text { Phaeosphaeria. }\end{array}$ & $\begin{array}{l}\text { Not present in } \\
\text { New Zealand. } \\
\text { New organism. }\end{array}$ & $\begin{array}{l}\text { Everett et } \\
\text { al. } 2011 b\end{array}$ \\
\hline $\begin{array}{l}\text { Neonectria fuckeliana } \\
\text { (Ascomycota) } \\
\text { (on Pinus radiata) }\end{array}$ & $\begin{array}{l}\text { Herbarium specimens and isolates of the } \\
\text { exotic fungus held in Scion collections } \\
\text { examined and dated back to } 1997 .\end{array}$ & $\begin{array}{l}\text { Organism found } \\
\text { in NZ before } 1998 . \\
\text { Not a new organism. }\end{array}$ & $\begin{array}{l}\text { Dick et } \\
\text { al. } 2011\end{array}$ \\
\hline $\begin{array}{l}\text { Neobulgaria alba sp. } \\
\text { nov. (Ascomycota) } \\
\text { (on Actinidia deliciosa) }\end{array}$ & $\begin{array}{l}\text { New fungal species found on in kiwifruit } \\
\text { vine wood and fallen wood in native } \\
\text { forests. }\end{array}$ & $\begin{array}{l}\text { Native. Not a new } \\
\text { organism. }\end{array}$ & $\begin{array}{l}\text { Johnston } \\
\text { et al. } \\
2010\end{array}$ \\
\hline
\end{tabular}

would appear to make this option impracticable. For example, the controls may include: limiting the dissemination or persistence of the organism in the environment (Section 38D (e)); or requiring the disposal of any organisms (Section 38D (f)). If these containment controls could be met then the new pest or disease could very likely be eradicated. It is conceivable that an application requiring the research and management that resulted in the reduction or even eradication of the organism could be approved.

The EPA may approve importation or field testing of any new organism in containment including field testing or maintaining new organisms in containment to produce antigens, biopesticides, biopharmaceuticals, enzymes, hormones, or vaccines, for diagnostic purposes, and/or other purposes the Authority thinks fit (Section 39). While this would allow a range of activities in containment useful for the development of pest and disease management strategies and tools, it would not allow for the validation of these strategies and tools in the pasture, orchard, crop, forest or natural system where they are actually needed. It many cases it may lead to the paradoxical situation where the activities are carried out on a organism in a containment facility that is itself surrounded by that same organism in the crops or fields surrounding it. The enforcement of such controls would be difficult and/or would add an additional burden on research programmes to develop suitable marking techniques.

Section 25 (1B) of the HSNO Act allows for MPI or 'its agents', to isolate, aggregate, multiply, or use an incidentally imported new organism for the purpose of identifying, managing, or eradicating that organism. This option seems to be seldom used to undertake research into the ongoing management of new pests and diseases. 
If the 'agent' provision section of the HSNO ACT is not used then the only meaningful mechanism allowing plant protection workers to respond effectively to a new pest or disease incursion of a 'new' organism is to have these organisms made 'not new' under Section 140 (1) (ba) of the Act (EPA no date). Under this section regulations can be made to prescribe organisms as 'not new' organisms. This change requires the making of new regulations and obtaining Cabinet approval. In 2010, the Ministry for the Environment instigated an annual process to allow this to happen. However, there is no statutory timeframe associated with this process.

In May 2011, Plant \& Food Research applied to the Ministry for the Environment (MfE) to make 'not new' a range of plant pests and diseases. These species were all significant pests or diseases of horticultural crops (i.e. tomato potato psyllid (TPP) (B. cockerelli), Candidatus Liberibacter solanacearum, Australian citrus whitefly (Orchamoplatus citri), lettuce aphid (Nasonovia ribisnigri), intonsa flower thrips (Frankliniella intonsa), and the honey bee parasite (i.e. varroa mite (Varroa destructor)). Each species required urgent and on-going research into their management, as they had formed breeding populations within New Zealand and were widely dispersed throughout the country. MPI no longer had any intention of trying to eradicate them. The amendment was passed on 29 August 2011 (SR 2011/299; Hazardous Substances 2011). These organisms are now considered 'not new' organisms and therefore do not fall under the authority of the HSNO Act. The process, which included consultation with MfE, EPA, MPI, researchers, horticultural industry groups, local government, iwi organisations and other affected parties, took from March until August 2011.

While the annual process for making organisms 'not new' is a step in the right direction, it may still lead to challenges in the rapid management of new pest and disease incursions. If a new incursion occurs soon after the annual call, the chance to make a new organism 'not new' may not occur for another year. In the meantime, research on that new organism is restricted by the HSNO Act to containment (after obtaining appropriate authority). Based on the statement 'from time to time', presumably new organisms can be made 'not new' outside this cycle, but this has not happened to date. This would be influenced by the importance of the pest or disease and the Cabinet and Parliamentary orders of business. A more pragmatic approach would be to have an organism made 'not new' as soon as MPI had determined that eradication was not feasible. MPI could then retain (or invoke) the 'unwanted' status of that organism as required. The major difficulty in making an organism 'not new' is the requirement for an Order in Council, which requires Cabinet time to be available. Another pragmatic solution would be to delegate the decision-making power to the EPA, so that cost-effective and time-bound decisions could be made. However, such a delegation would require further policy consideration.

\section{SUMMARY}

Plant protection researchers need to be aware of the legal restrictions placed upon them by the Biosecurity and HSNO Acts when undertaking research on 'unwanted' and 'new organisms'. In many cases these limitations may seem counterproductive for the improved management of pest and disease organisms. MPI, MfE and EPA need to ensure that information on the status of these pests is clear and easily accessible, and that they expedite appropriate changes in 'unwanted' and 'new' status as rapidly as possible. Consideration needs to be given to changing the legislation with respect to 'new' organisms, so that appropriate research can be initiated and conducted much more rapidly.

\section{ACKNOWLEDGEMENTS}

We thank Max Suckling for useful comments on an earlier draft of the manuscript. Warrick Nelson, Stuart Ritchie and Philippa Stevens provided valuable discussion in relation to this subject, which was taken into account in the development of this manuscript. An earlier draft of this manuscript was provided to MPI (George Gill) for comment. The research was carried out under the Better Border Biosecurity (B3) collaboration. 


\section{REFERENCES}

Bickel TO, Closs GP 2008. Impact of Didymosphenia geminata on hyporheic conditions in trout redds: reason for concern? Marine and Freshwater Research 59(11): 10281033.

Biosecurity Act 1993. Public Act 1993. No 95. Date of assent 26 August 1993. Reprint as at 22 April 2010. New Zealand Government, Wellington, New Zealand.

Brockerhoff EG, Liebhold AM, Richardson B, Suckling DM 2010. Eradication of invasive forest insects: concepts, methods, costs and benefits. New Zealand Journal of Forestry Sceince 40 Supplement: S117-S135.

Dick MA, Power MWP, Carlson CA 2011. Neonectria fuckeliana infection of Pinus radiata nursery stock. New Zealand Plant Protection 64: 183-187.

Eastop VF 2011. Megoura stufkensi a new species of aphid (Hemiptera: Aphididae) from New Zealand. New Zealand Entomologist 34: 27-29.

Eerens JPJ, Hardwick S, Gerard PJ, Willoughby BE 2005. Clover root weevil (Sitona lepidus) in New Zealand: the story so far. Proceedings of the New Zealand Grassland Association 67: 19-22.

EPA no date. Making new organisms "not new" by regulation. Environmental Protection Authority http://www.epa.govt.nz/ new-organisms/popular-no-topics/Pages/ Making-not-new-by-regulation.aspx (accessed 24 April 2012).

EPA 2011. To determine whether Pseudomonas syringae pathovar actinidiae ( $\mathrm{Psa}$ ) is a new organism for the purposes of the HSNO Act. ERMA200990. Environmental Protection Authority, Wellington, New Zealand.

Everett KR, Taylor RK, Romberg MK, Rees-George J, Fullerton RA, Vanneste JL, Manning MA 2011a. First report of Pseudomonas syringae pv. actinidiae causing kiwifruit bacterial canker in New Zealand. Australasian Plant Disease Notes 6: 67-71.

Everett KR, Rees-George J, Pushparajah IPS, Manning MA, Fullerton RA 2011b. Molecular identification of Sphaceloma perseae (Avocado scab) and its absence in New Zealand. Journal of Phytopathology 159 (2): 106-113.
Flynn AR, Stufkens MAW, Teulon DAJ 2003.

Distribution and flight activity of the Monterey pine aphid in New Zealand. New Zealand Plant Protection 56: 33-38.

Froud KJ, Popay IA, Zydenbos SM ed. 2008. Surveillance for Biosecurity: Pre-Border to Pest Management. New Zealand Plant Protection Society, New Zealand. ISBN 978-0473-14188-2.

Goldson SL, Suckling DM 2003. Defending the Green Oasis: New Zealand Biosecurity and Science. New Zealand Plant Protection Society, New Zealand. ISBN 0-473-09386-3.

Hazardous Substances 2011. SR 2011/299: Hazardous Substances and New Organisms (Organisms Prescribed as Not New Organisms) Amendment Regulations 2011. Published under the authority of the New Zealand Government, Wellington, New Zealand http://www.legislation.govt.nz/regulation/ public/2011/0299/latest/DLM3952313.html (accessed 15 May 2012).

HSNO 1996. Hazardous Substances and New Organisms Act 1996. New Zealand Legislation http://www.legislation.govt.nz/ act/public/1996/0030/latest/DLM381222.html (accessed 24 April 2012).

Johnston PR, Park D, Manning MA 2010. Neobulgaria alba sp. nov. and its Phialophoralike anamorph in native forests and kiwifruit orchards in New Zealand. Mycotaxon 113: 385-396.

Kriticos DJ, Phillips CB, Suckling DM 2005. Improving border biosecurity: potential economic benefits to New Zealand. New Zealand Plant Protection 58: 1-6.

Liebhold AM, Brockerhoff EG, Garrett LJ, Parke JL, Britton KO 2012. Live plant imports: the major pathway for forest insect and pathogen invasions of the United States. Frontiers in Ecology and the Environment 10: 135-143.

MAF Biosecurity New Zealand 2008a. Policy for MAF's Responses to Risk Organisms. ISBN 978-0-478-32159-3. http://www.biosecurity. govt.nz/files/biosec/consult/response-policyrisk-organisms.pdf [accessed 20 April 2012]. 
MAF Biosecurity New Zealand 2008b. Biosecurity Act 1993. www.biosecurity.govt.nz/biosec/ pol/bio-act [accessed 24 April 2012].

MAF Biosecurity New Zealand 2010a. Unwanted organism permission application form. http://www.biosecurity.govt.nz/forms/uopermission-app-form [accessed 24 April 2012].

MAF Biosecurity New Zealand 2010b. Unwanted organisms register. http://www.biosecurity. govt.nz/pests/registers/uor [accessed 24 April 2012].

Monds RD, Cromey MG, Lauren DR, di Menna M, Marshall J 2005. Fusarium graminearum, F. cortaderiae and F. pseudograminearum in New Zealand: molecular phylogenetic analysis, mycotoxin chemotypes and coexistence of species. Mycological Research 109 (4): 410-420.

Morgan R 1998. Goodbye tussock moth. Forest Health News 76:1.

Myers JH, Simberloff D, Kuris AM, Carey JR. 2000. Eradication revisited: dealing with exotic species. Tree 15 (8): 316-320.

Suckling DM, Barrington AM, Chhagan A, Stephens AEA, Burnip GM, Charles JG, Wee SL 2007. Eradication of the Australian painted apple moth Teia anartoides in New Zealand: trapping, inherited sterility, and male competitiveness. Vreysen MJB, Robinson AS, Hendrichs J ed. Area-wide control of insect pests: from research to field implementation. Springer, Dordrecht, the Netherlands. Pp. 603-615.

Rugman-Jones PF, Hoddle MS, Stouthamer $R$ 2010. Nuclear-mitochondrial barcoding exposes the global pest Western flower thrips (Thysanoptera: Thripidae) as two sympatric cryptic species in its native California. Journal of Economic Entomology 103: 877-886.

Teulon DAJ, Workman PJ, Nielsen M-C 2009. Bactericera cockerelli: Incursion, dispersal and current distribution in New Zealand. New Zealand Plant Protection 62: 136-144.

Upton S 1999. Risk. The Robert C Barnard Inaugural Lecture. The Right Honourable Simon Upton, Minister for the Environment New Zealand. Delivered to the American Association for the Advancement of Science, Washington DC, United States of America, September 1999, p 4-5. http://www.arcadia. co.nz/risk/index.htm (accessed 24 April 2012). 